\title{
Jean François Niceron: Perspective and Artificial Magic
}

Agostino De Rosa

Full Professor

Department of Architecture and Arts/DCP University luav of Venezia, Venezia

The essay deals with the perspectival and artistic work of Minim Father Jean François Niceron (1613-1646), whose life was expressed in a very short period of time - just 33 years - but full of political and cultural events, reflected in works offered today to the eyes of the contemporary observer as extraordinary charades, in perfect ballance between mathematical rigor and taste for the wonderful and amazing. Author of two treaties (the second of which published posthumously) which have become milestones in studies of Seventeenth-century perspective - La perspective curieuse (Paris 1638) and the Thaumaturgus opticus (Paris 1646) -, Niceron early developed from his expressive world which he translated in acutely deceptive works: catoptric anamorphoses, refractive games and murals in accelerated perspective (the only one survived, depicting St. John the Evangelist writing the Apocalypse in Patmos, it is now visible at the Convent of SS. Trinita dei Monti, Rome), to name a few types.

Keywords: History and Theory of Representational Methods; History of Descriptive Geometry; History of Science; Perspective in Art; Catoptric in Art

\section{INTRODUCTION}

\section{P. IOANNIS FRANCISCO NICERONO. GENI DEL MIRABILIBVS SVI OPERIBVS}

The portrait shows a young monk with an the emaciated face, outlined by a barely visible beard wearing a tunic with cap typical of the Minim religious Order, and holding in his hand the planche of his latest treatise, to which he was still working just before his death, September 22 1646. The engraving executed by Michel Lasne (1595-1667) appears as a space-time paradox, especially sinc1e the subject of the portrait will not have the actual time to see his last work published; in fact, he also holds - in the image - this work in his hands, but it will only be published posthumously. If his body is pointing at the book, his face and especially his eyes are pointing elsewhere, beyond the limits of the illustrated page, toward a light source which is reflected in his terse pupils, oriented outside the religious and scientific circles - located in Rome and Paris - in which the young minimum monk lived for most of his short life. JeanFrançois Niceron in fact died in Aix-en-Provence at the Christological age of 33, having spent his youth in the exercise of faith, in scientific research and testing a bizarre but fascinating application of the theory of artificial magic to the world of images and to perception. The traces of this existence are rarefied, like paths dispersed in a suddendly shrouded mist clearing, and for the scholar it is difficult to approach it with so

Received: June 2016, Accepted: October 2016

Correspondence to: Prof. Agostino De Rosa,

Department of Architecture and Arts/DCP

University Iuav of Venezia, Venezia, Italy

E-mail: aderosa@iuav.it

doi:10.5937/fmet1702215D

(c) Faculty of Mechanical Engineering, Belgrade. All rights reserved few landmarks. Few direct documents, but many indirect references to his life; appreciation from the most remarkable minds in Europe at the first half of XVII century, and then the corpus of his scientific and artistic work, often neglected and overlooked: these are the coordinates that offer themselves to those who face the description of Niceron's world, echoed in the celebratory verses that accompany his portrait: 'R. P. Joannes Franciscus Niceron ex Ordine Munimorum, egregiis animi dotibus et singulari matheseos peritia celebris, obiit Aquis Sextiis 22 septembris an. Dni 1646, Æat 33. Ære micat mentis vis ignea, vultibus ore: Ars tibi, quid fingis? Suæ Niceronis erat.' Already looking at his only official effigy, as I wrote, raises some observations that somehow summarize the karst and oblique track of Father Niceron's short life. Although it falls into the stylistic trend of first half of the Seventeenth century's scholars typical portraits ${ }^{1}$, which anticipate the subject's iconographic memorialisation before his/her death, the image outlined by the Lasne, in his seemingly dry and ascetic physiognomic approach, offers some optical-perspectival inconsistencies.

The curtain behind the Minimum Father is raised, in order to let us glimpse, from a compartment doors, Pincio's Roman landscape and, above all, the convent of SS. Trinita dei Monti - where Niceron stayed accidentally oriented compared with the picture's plane: we just see the building's base, in part we see the double ramp that provides access to the convent church

\footnotetext{
${ }^{1}$ See Mayer-Deutsch, A., 2004. 'Quasi-Optical Palingenesis'. The Circulation of Portraits and the Image of Kircher, in Athanasius Kircher: the last man who knew everything (P. Findlen, edited by), Routledge, London, pp.105-129; Kathke, P.,1997. Porträt und Accessoire: Eine Bildnisform im 16. Jahrhundert, Reimer, Berlin.
} 
which stands in all its elegant symmetry, with the two bell towers of French taste. On plaques that Niceron holds upright we read, at the bottom: "F. Iaon Franciscus Niceron/ Delinea Romæ ano Sal. 1642/Ætatis Suæ 29”. This suggests that it was drafted during the second Roman stay of Niceron (post January 1641- April 1642) and that in that period, the author was drafting the Latin edition and the related plates of his $L a$ Perspective Curieuse (1638), a treatise dedicated to unlocking the secrets of the aberrate perspectives known as anamorphosis [1].

The use of French had stolen the treatise to a wider spread among scholars from all over Europe. The illustration selected by Niceron is the number 13 depicting the Propositio Trigesima (30) dedicated to the perspectival representation of a "starry spherically solid with square based pyramids." 2 This subject's choice was probably linked to the new theme that it symbolized, thus suggesting, graphically, the expansion of the Latin edition respect the French one [2].

\section{JEAN FRANÇOIS NICERON: A LIFE BETWEEN ART AND SCIENCE}

Niceron $^{3}$ was born in Paris July 5, 1613 from Claude Niceron and Reneé Barbier who baptized him with the name of François: elder of two brothers and two sisters, after conducting his first studies at the Collège de Nevers ${ }^{4}$ (Paris), at the age of 19, in 1632, orphan of his father, he joined the Order of the Minims, at the convent of Nigeon-Chaillot ${ }^{5}$ (now Passy), where he serves as a novice. On January 26, 1632, after having completed his novice, he was admitted to the profession and then to the convent of Place Royale (Paris) in the same year ${ }^{6}$. Here he assumed the second name, Jean, in homage to

\footnotetext{
${ }^{2}$ Niceron, J.F., 1646. Thaumaturgus opticus, Paris, I Book, pp. 94-97.

${ }^{3}$ The sparse biographic information about J.F. Niceron's life are derived from: Withmore, P.J.S., 1967. The Order of Minims in Seventeenth-Century France, Springer, The Hague. pp. 155-162; Roberti, G.M., 1902-1908. Disegno storico dell'Ordine dei Minimi, 3 voll. Tip. Poliglotta, Rome; Correspondance de Mersenne, VIII-XII, with a brief biography in X, p. 811; Niceron, J.-P., 1729. Mémoires pour servir à l'histoire des hommes illustres dans la république des lettres, avec un catalogue raisonné de leurs ouvrages, volume VII, Paris. pp. 153-156 (reprint 1971.Geneva, Slatkine, pp. 681-682) with some adds in the $\mathrm{X}$ volume, Paris 1730 , pp. 175-176.

${ }^{4}$ See Crosnier, A.J., 1877-1881. Les congrégations religieuses dans le diocèse de Nevers, Paris. pp. 512-515. More biographical references say that Niceron, during his stay at the college of Nevers, performed his studies under the guidance of Father Mersenne who recognized his precocious, intuitive abilities in mathematics. In fact, Mersenne returned to Paris from Nevers in 1619, when Niceron was only six years. See Malcolm, N., 2004. Aspects of Hobbes, Oxford University Press, Oxford p. 211. See also: Lenoble, R. , 1943. Mersenne ou la naissance du mécanisme, Vrin, Paris. pp. 22-23.

${ }^{5}$ This is the monastery built on the manor - called Nigeon - where Anne of Brittany, in 1491, hosted the first group of Minim friars. Its convent church was inaugurated in 1578. See Hélyot, P., Bullot, M. 1718. Histoire des ordres monastiques, religieux et militaries.., Paris.

${ }^{6}$ See Thuillier, R., 1709. Diarium patrum, fratrum et sororum ordinis minimorum provinciae Franciae sive Parisiensis, qui religiose obierunt ab anno 1506 ad annum 1700. 2 voll., Paris (anastatic reprint: 1972. Slatkine Reprints, Geneva). vol. I, pp. 141-2; vol. II, pp. 143-4.
}

his uncle, who was also ordered Minimum. At that historical moment, the Order founded by St. Francis of Paola $^{7}$ (1416-1507, canonized in 1519) counted 457 monasteries in Europe (of which 150 in Italy and 156 in France), and Niceron's transition from the Nigeon parish of Place Royale's prestigious convent ${ }^{8}$ - founded by Maria de 'Medici in 1605, and not yet been completed at that time - was a certification of the young devotee's scientific potential, who, in observance of the Minim Rule, could reconcile the exercise of Christian charity with the practice of scientific studies [3].

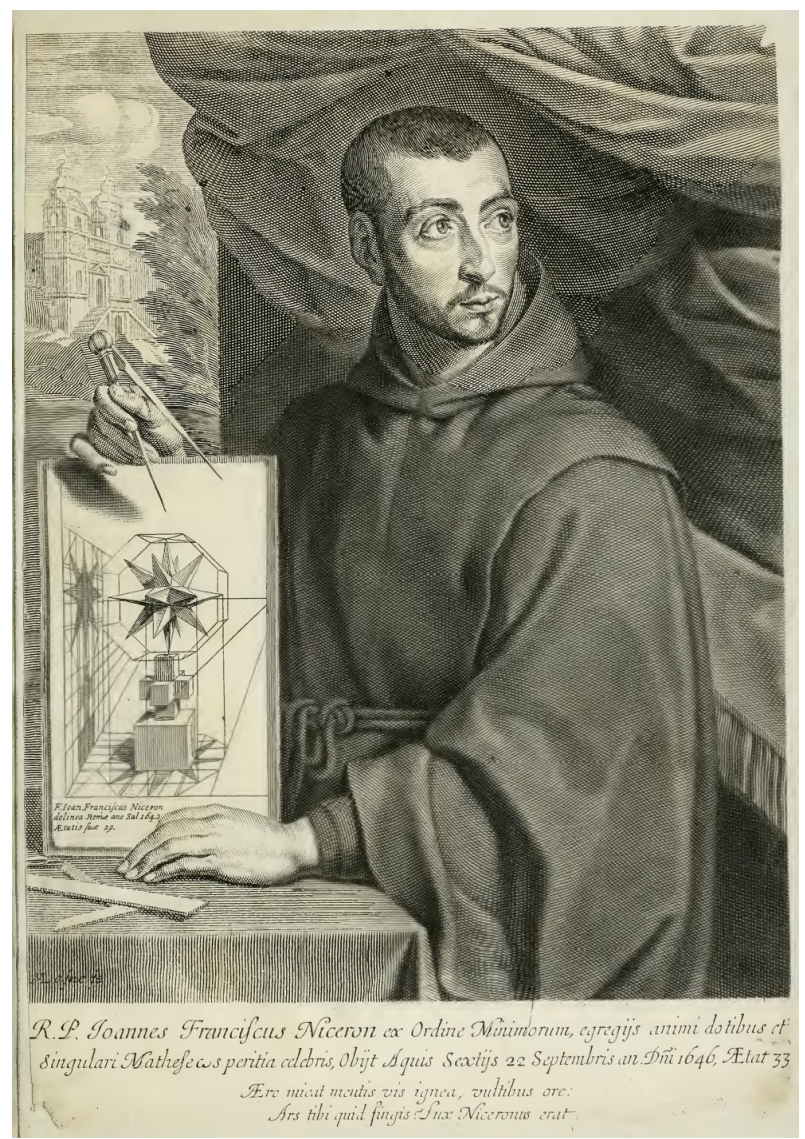

Fig. 1. M. Lasne, R. P. Joannes Franciscus Niceron ex Ordine Minimorum, egregiis animi dotibus et singulari matheseos peritia celebris, obiit Aquis Sextiis 22 septembris an. Dni 1646, Aetat 33. Engraving. Paris, first half of XVII century.

During the novitiate in 1631 , at the age of 18 , Niceron had already designed his first artistic work, an anamorphic portrait of Jacques d'Auzolles de Lapeyere (1571-1642), famous author of Mercure charitable ${ }^{9}$,

${ }^{7}$ On the life of St. Francis of Paola, and on the history of the Minims, see: Fiorini Morosini, G. , 2000. The penitential charism of St. Francis of Paola and the Order of the Minims. History and spirituality. Bibliotheca Minimum 3, Roma.

${ }^{8}$ See Krakovitch, O., 1981. Le couvent des Minimes de la PlaceRoyale, in Paris et Ile-de-France-Mémoires. tome 30, Klincksieck, Paris; Id. L'architecture des trois couvents des Minimes de la PlaceRoyale, in (P. Benoist, A. Vauchez, edited by), Saint François de Paule et les Minimes en France de la fin du XVe au XVIIIe siècle. $\mathrm{P}$ U De Rennes, Tours. pp. 229-248; (Christ, Y., Siguret, P., de Sacy, J. S., edited by), 1964. Le Marais. Andre Balland, Paris.

${ }^{9}$ See d'Auzoles de Lapeyre, J., 1638. Le Mercure charitable, ou Contre-Touche et souverain remède pour desempierrer le R. P. Petau, jésuite d'Orléans, depuis peu métamorphosé en fausse pierre-de- 
which he inserted in his work, providing chronological details about it on its back side: it is an aberrated image, outlined and engraved by J. Picard, radiating itself on a horizontal surface, and it becomes recomposed when it's reflected on a mirror-treated cylinder, placed inside of it, right in the image identified by the writer's 'rectified' portrait - executed in a medal shape -, defined by the same Niceron, princeps chronographorum. It is evident that at the time of the portrait of Jacques d'Auzolles, Niceron could not yet have read some seminal works by René Descartes ${ }^{10}$ (1596-1650), as the Dioptrique (1637) or the Géométrie (1637) which will be centered on the theme of perception and mistakes to which the senses inevitably condemn us: sure he will consult them later, attending both the Library of the Order of the Minims's Convent in Place Royale (Paris) (which gathered in addition to the precious volumes and incunabula, even many scholars who frequented the intellectual circle of Father Marin Mersenne ${ }^{11}$ (15881648), secrétaire de l'Europe savante, in his cell every Saturday). Scholars who gathered there - such as those who corresponded with him from all over Europe - were mostly interested in philosophical and mathematical questions and especially in the implications that the ideas of mechanism and of vacuum could result in the study and in the reproduction of natural phenomena: Niceron's work, since his first artistic and scientific experience, is an attempt to escape from the inexorable idea of the mechanism, to identify "... a strategy to avoid the reduction of appearances to the laws of inert matter, or rather, to find a way through which, in itself, the appearances of material bodies were recognizable and oriented themselves to the spirit, reflected their otherness and their principle, not to be reduced to the size of the res extensa, the strict mechanistic model and spatial partes extra partes." 12

It is likely that Niceron had seen the first catoptric anamorphoses in Paris in 1627: they would be some exotic specimens imported into France by the painter Simon Vouët (1590-1649) on his return from a trip to Constantinople, and which he purchased there between 1611 and $1612^{13}$. However, the work seems to have been carried out without any 'projective' awareness by the young Niceron, but with so convincing results that the same Jaques d'Auzolles defines him as: “...trèsexcellent esprit et très-savant homme (si alors on le

touche, par Jacques d'Auzoles Lapeyre. in-fol., G. Alliot, Paris. The catoptrical anamorphosis is reproduced at page 73 .

\footnotetext{
${ }^{10}$ See Rodis-Lewis, G., 1997. Cartesio. Una biografia. Editori Riuniti, Roma.

${ }^{11}$ The fundamental work on his life and his work remains: de Coste, H., 1649. La vie du R. P. Marin Mersenne, théologien, philosophe et mathématicien, de l'Ordre des Peres Minimes, par F. H. D. C. [Frère Hilarion de Coste], religieux du mesme Ordre. A Paris, chez Sebastien Cramoisy et Gabriel Cramoisy, MDCLIX, in-12 ${ }^{\circ}$. Paris.

12 Baitinger, F-C., 2006. L'esprit du portrait ou le portrait de l'esprit/Etude d'un portrait en anamorphose de Jacques d'Auzoles par le père $\mathrm{J}-\mathrm{F}$ Niceron, in Lampe-tempête, $\mathrm{n}^{\circ} 1$, le silence de l'expérience. November, without any indication of page.

${ }^{13}$ See Siguret, F., 1993. L'oeil surpris. Perception et représentation dal la $1^{\text {ère }}$ moité du XVII siècle. Klincksieck, Paris. p. 191.
}

devait appeler homme, n'ayant que quelque dix-huit ans) en tout ce qui dépend de l'optique; ce gentil esprit lors que moins j'y pensais s'avisa de faire de mon portrait la suivante figure, laquelle semble plutôt un monstre qu'un homme, mais y appliquant un cylindre et le mettant sur le rond qui est marqué cela me représente si naïvement bien, qu'il ne s'est fait portrait de moi soit plus semblable." 14

To this class of images, to be inserted into catroptric regenerative devices, also belong the four oils on canvas (made in Paris in 1635 or so), of small size (50 x 66.5 $\mathrm{cm})$, rectifiable through their reflection on cylindrical mirrors, today at the National Gallery of Ancient Art in Palazzo Barberini (Rome), and portraying respectively: Louis XIII before a crucifix, Louis XIII, San Francesco di Paola, and a Nuptial scene. ${ }^{15}$ The amazing effect of the reflective reconstruction of these deformed images is obtained by Niceron applying the geometric constructions also present in his 1638 'vernacular' treatise - revised and refined in the posthumous edition which were based on those once developed by the French mathematician Jean-Louis Vaulezard $\left(* *_{-}^{*}\right)$, in his Perspectivae cilindrique et conique ou traite des apparences vues par le moyen des miroirs... ${ }^{16}$ (Paris 1630 with the aim of being used by his students who made him this request: they envisaged an initial planar anamorphical deformation of the figure, and then its catoptrical 'transformation'. Interestingly, the process proposed by Vaulezard was based on the use of simultaneous double orthogonal projections - plan and elevation - of the given object, simultaneously present in the preparatory table, and this choice is an anticipation of what we now know as Monge method. This method, only codified in the late Eighteenth century, was already used by numerous treatises and architects in the absence of its full projective awareness, which appears here instead entirely intuited. The diagrams, designed to be projectively consistent by Niceron, constitute, since 1638 onwards, the obligatory point of reference for operators who will compete with the complex world of catoptric anamorphosis, whose diffusion was due, as well as to Jean Dubreuil (16021670), to Mario Bettini (1584-1657), Athanasius Kircher (1602-1680) and Gaspar Schott (1608-1666), a pupil of Mersenne ${ }^{17}$. Without neglecting the study of theological and philosophical disciplines, the young Jean Francois had a special inclination for mathematical studies and a considerable interest in optics, catoptric

\footnotetext{
${ }^{14}$ d'Auzoles de Lapeyre, J., 1638. Le Mercure charitable, ou ContreTouche et souverain remède pour desempierrer le R. P. Petau, jésuite d'Orléans, depuis peu métamorphosé en fausse pierre-de-touche, par Jacques d'Auzoles Lapeyre. in-fol., G. Alliot, Paris. pp. 72-73.

${ }^{15}$ Inventory numbers: 1953, 1954, 1955, 1956. See Camerota, F., edited by, 2001. Nel segno di Masaccio. L'invenzione della prospettiva. Giunti, Florence. p. 180.

16 See Andersen, K., 1996. The mathematical treatment of anamorphoses from Piero della Francesca to Nicéron, in History of Mathematics: States of the Art. San Diego.

${ }^{17}$ See Füsslin, G. , Hentze, E. , 1999. Anamorphosen. Füsslin Verlag, Stutgart; De Meyere, J. , Weijima, H. , 1989. Anamorfosen. Kunst met een omweg. Aramith, Bloemandaal.
} 
and dioptric, which channeled in his first treatise: only in that year, in fact, the twenty-five years old Niceron published in Paris at Pierre Billaine, La Perspective Curieuse, ou magie artificielle des effets mervellieux... (1638), a work influenced by texts of Salomon de Caus (La Perspective, London 1612), and of the aforementioned Jean -Louis Vaulezard (Abrégé ... de la perspective par l'imitation, Paris 1635), and yet also more original than most of his famous predecessors. The in-folio work consists of 20 unnumbered pages (including l'Epistre, la Permission du R.p. Provincial de l'Ordre des Minimes en la Province de France, il Sommaire de ce qui est contenu and the Preface et advertissement), 120 numbered pages (including the Preludes geometriques, the Definitions necessaires and the books I-IV) ${ }^{18}$, two more unnumbered pages and 25 plates, whose illustrations were engraved by Joan Blanchin but based on Niceron's drawings, whose graphics abilities seem undoubtable, as proved by his aforementioned first texts in the wolrd of arts. Aware of the degree of sophistication that perspectival technique had reached during the Sixteenth and early Seventeenth century, Niceron addresses the problem of deformation with an approach that today we might call 'projective' avant la lettre, abandoning the practical expedients now widely exploited,"... because it is a matter of small weight and for which it is not necessary to have any knowledge of perspective." ${ }^{19}$ In his treatise the Minim Father, showing a deep understanding of the perspective theories formulated by his predecessors, both Italian and French and German, takes a leading role in the development of the discipline, steering towards an 'Archimedean' approach rather than a 'platonic' one in the espositive issues, which are focused more on the application side of a topic than on the abstractly speculative one.

The optic primacy is quickly established, in that, between the senses, the vision just dominates, as Descrates himself asserted in his preface to $L a$ Dioptrique. With clear and rigorous language, Niceron proposes and solves many problems of linear perspective, accompanying the theoretical explanation with the beautiful plates engraved by Blanchin. The intention of Father Niceron is not to edit a critical document summary of the best earlier treatises, but to deal with "... kindness of the curious perspective, which, as they have amused him and distracted from the seriousness of theological studies, may not be disagreeable to the curious." ${ }^{20}$, One of the critical elements that emerge from the niceronian anamorphic

\footnotetext{
${ }^{18}$ The Four Books in which La Perspective curieuse is divided are dedicated, in order: Book I, to general principles of perspective, to their application to the five regular Platonic polyhedra and to other solid bodies; Book II, to planar anamorphosis and to the description of a perspectograph called Instrument Catholique (later, Scenographum Catholicum in the edition of 1646); Book III, to catoptric and to reflective anamorphosis; the Book IV, to Dioptrics and its anamorphic applications. See Vagnetti, L., 1979. De et natural artificial perspectiva. Libreria Editrice Fiorentina, Firenze. pp. 392-393.

${ }^{19}$ Niceron, J. F., 1638. La perspective curieuse. Paris. p. 90.

${ }^{20}$ Ibid.
}

treatment is the unprecedented upheaval of the ontological set provided from the common perspective, which classically foresaw the figurative plane arranged between the eye and the object to be represented: Niceron undermines this liturgy, admitting that the object can be placed accidentally between the other two elements, so as to produce further distortions in projective phase, primarily the effect that anamorphic image projects towards the observer, once it has been rectfied.

The beginnings of this projective approach must be found in Piero della Francesca, and in particular in its perspective of a rinfrescatoio with pedestal, subject of fig. LXXIX of his De Prospectiva Pingendi (ca 1482). Later Niceron insists in remembering that he had used the word 'magic' in his treatise's title not to allude to prohibited, esoteric or occult practices, but to refer, as it happened with Giambattista della Porta ${ }^{21}$, to those effects merveilleux that will be shown through the perspective, this one indeed a magie artificielle; according to historian Amodeo $^{22}$, it was precisely because of the word 'magic' included in the title of his work, that the copies of the first edition of Niceron's treatise disappeared in a short time, maybe withdrawn by the ecclesiastical authorities because they considered it heretical. However, for Niceron, perspective was not just a form of recreations de savants, but one of those racy exercises of phenomenal mimesis of the world to which belonged also the fabulous balls by Posidonius (135 BC-50 BC), a planetarium which imitated the motions of the heavenly spheres; or the wooden flying dove by Archita (428 BC-347 BC); or even the bronze talking head made by Albertus Magnus (1206 -1280): a plethora of automates whose purpose was therefore to compete with the wonders of nature, and to which René Descartes himself made referenced to in the introduction of the Latin edition of his Traité de l'homme (1648), showing they have used the same Niceron's literary source, namely De occulta philosophia (1531) by Cornelius Agrippa (1486 -1535). The center of La Perspective Curieuse remains the anamorphosis: the subject is so developed by Niceron in its geometric and figurative (direct and indirect) implications that it soon became the reference text in the specialist studies and his author became an auctoritas summa on the subject. It's significant that the theme of anamorphosis finds its own more exhaustive exegesis in the scientific texts elaborated by religious stationed in Rome, and in particular in The Perspective Curieuse by our Jean Francois Niceron and in subsequent Latin edition, published posthumously in 1646, edited by Minim Father M. Mersenne, and entitled Thaumaturgus opticus seu admiranda. Optices for radium directum; catoptrices for reflexum and 'Politis corporibus, Planis,

\footnotetext{
${ }^{21}$ See: della Porta, G.B. 1589. Magia Naturalis, libri XX. Neaples. See also: Hammond, J.H., 1981. The camera obscura. A chronicle. Hilger, Bristol; Pesenti Campagnoni, D., 1995. Verso il cinema. Macchine, spettacoli e mirabili visioni. UTET Università, Torino.

${ }^{22}$ See: Amodeo, F., 1933. Lo sviluppo della Prospettiva in Francia nel secolo XVII, in Atti dell'Accademia Pontaniana, vol. LXIII. Neaples. pp. 24-25
} 
cylindricis, polyedris, poligonis, et aliis; Dioptrices for rifractum in diaphanis. As reported by Ilaria Rizzini ${ }^{23}$, the latter work was intended as a partial realization - for economic and biographical issues - of the publishing project that Niceron cultivated for many years and that, before to the Minim Community undertakings, and then an early death, prevented him from carrying it out. In the text Niceron deforms, in strongly aberrated perspective, besides human figures, the images of common objects, such as a chair and a bench of which are offered, of the first, a distorted version in depth and, the other, in width, but which magically rectify themselves when observed under a very acute viewing angle and from a suitable position. The observer thus becomes consubstantial to that point with the image, instinctively becoming closer to the picture plane and trying to solve its meaning, and at the end collapsing on it: the cancellation of this hiatus, indispensable to solve the cathartic game in which the initial doubt is followed by visual uncertainty and finally the renewed domain on the image which, according to Lyle Massey, is inscribed in a process of acquiring visual certainty, in which the viewer becomes one with the thing observed; process that is coupled with the established Cartesian ontology grounded "... on a point of view model which depends on a despatialized vision...

What distinguishes anamorphosis from cogito is that anamorphic point resists Cartesian recovery of the knowledge of self reaffirming instead the division of a subject that has torn both epistemological and ontological certainty." 24 One of the most interesting sections of the work is contained in Book III, whose content Niceron sums up didactically, revealing how it is entirely dedicated to the study "... of the appearance of flat, cylindrical and conical mirrors, and how to build figures which are related and represent through reflection to something quite different, of what appears being viewed directly." ${ }^{25}$ Here the influence carried out by Vaulezard's work is clear and accepted by the author himself, although Jean-François Niceron will devote to deepen both experimental and theoretical aspects related to catoptric anamorphoses, proposing two procedures for the construction of the reflective anamorphosis, in particular the cylindrical one. In Table 18 (Fig. LIII, LIV, LV) of La Perspective Curieuse also appear the instructions $^{26}$ to create an optical game consisting of several wooden slats of prismatic shape and with an isosceles triangular section, arranged in succession within a box, on whose visible faces Niceron portrays, in alternating sequence, the face of Francis I of France and the celebratory motto:"Franciscus/Primus/Dei Gratia/Francorum/Rex/Christianissimus/Anno

\footnotetext{
${ }^{23}$ See: Rizzini, I., October-December 2004. Il Thaumaturgus opticus di Jean-François Niceron: appunti in margine alla traduzione dal Latino, in Bollettino Ufficiale dell'Ordine dei Minimi, $\mathrm{n}^{\circ} 4$, year LI.

${ }^{24}$ Massey, L., Winter 1997. Anamorphosis Through Descartes or Perspective Gone Awry, in Renaissance Quarterly, Vol. 50, numebr 4. p. 1187.

${ }^{25}$ Niceron, J. F., 1638. La perspective curieuse. Paris. p. 72.

${ }^{26}$ Ivi. pp. $78-80$.
}

Domini/M.DC.XV." 27 The illusory effect allows us to see to its same dedication, "in faccia", and the real picture, "per via di sfera", that is, through the use of a mirror, ad hoc tilted, reflecting the surfaces's rulers not directly visible ${ }^{28}$. Here Niceron admits to have used two simple theorems taken from Euclid's Catoptrics (ca. $325 \mathrm{BC}-285 \mathrm{BC}$ ) to reach his deceptive purpose, in particular the Seventh and Nineteenth. Niceron also offers a variant of the first solution proposed, substituting, for the portrait of Pope Urban VIII, the prismatic triangular rulers with plan listels. James L. Hunt and John Sharp classify this type of device as a channel anamorphosis, in consonance with the definition tabula scalata provided by A. Kircher. James L. Hunt and John Sharp classify this type of device as a channel anamorphosis, in consonance with the definition provided by A. Kircher of tabula scalata $^{29}$, noting that its presence in the art world had already been reported by Shakespeare ${ }^{30}$.

The historian Frances Terpak identifies a classical lineage in this continuous bipolar device, associating it to the XV books of Metamorphoseon, the famous epic poem of Ovid (43 BC-18 BC) in which, in addition to the theme of magic and wonderful mutation, also marked dramatically by its latent hubris, emerges a hypotactic structure which is typical of anamorphosis, in particular of that which we are examining here: the plural articulation in interconnected subordinate with the text is coupled with the multiple semantic layers of the image, in its everchanging signifier but also in its multiple meanings and intertextual references. At the same hermeneutic profile also belongs a dioptric anamorphosis, present in the same collection of the Galileo Galilei Museum ${ }^{31}$ dedicated to the optics, sure executed on Niceron's advice and supervision around 1642 , and which consists of an oil painting on wood, attached to another horizontal tablet, on which is anchored, in front of the painting, a wooden pedestal bearing, in its upper part, a semi-cylindrical pilot-hole hosting a telescope. In the painted image are depicted several Turkish heads (arranged nearly radially around a trophy of arms and flags which occupies a central position in the composition), that then had to then had to be observed through the 'telescope' - equipped with a prismatic lens and a diaphragm -. This device was lost during the Florence flood of of 1966: only in this way it would appear, magically, a portrait of the Grand Duke Ferdinando II de 'Medici, obtained thanks to the refractive selection by the lens' facets, out of the

\footnotetext{
${ }^{27}$ Ivi. p. 79.

${ }^{28}$ See: Hunt, J. L., Sharp, J., 2009. The Channel Anamorphosis, in Journal of Mathematics and the Arts. Vol. 3. pp. 19-31. The authors agree on the use of the term channel anamorphosis, instead of the less correct definitions in use in ordinary or critical language (which employs improper adjectives as Corrugated, Stockade, Turning Pictures or lenticular).

${ }^{29}$ See: Kircher, A., 1646. Ars Magna Lucis et Umbrae. Roma. p. 904.

${ }^{30}$ See: Shickman, A., 1977. Turning Pictures in 'Shakespeare's England', in The Art Bulletin. Vol. 59. pp 67-70.

${ }^{31}$ Room I, inv. Number: 3196 (700x430x530 mm).
} 
Saracens' portraits. The work also presents an inscription, partially abraded, on the horizontal connection element referring, apparently to the role played by the Medici family, since the time of Cosimo $\mathrm{I}$, in financing the fleet which defeated the Turks in Mediterranean: it's not wrong to see the irony staged by this device whose implicit message is that it takes as many as 12 heads Turkish kings to make that one of King of France.

The most explicit recall, in philosophy, to this optical device is provided by Thomas Hobbes (15881679) who in his Leviathan (1651) employs its refractive logic closing the chapter on The rights of sovereigns by institutions. Of the two polyhedral lenses represented in the engraving of plate 23 , only the second (the one located to the right, in the drawing indicated with the number $L X V$ ) is also provided of the elevation, from which it is possible to derive its plausible spatial configuration.

The other (the one represented on the left, in the drawing shown with the number LXIV) must be associated to the next table 25 of the treatise, where Niceron apply the same construction to get through the dioptric recomposition of the 14 busts of many Popes and Fathers of the Church, rotating around the image of Christ, the portrait of Pope Urban VIII: note that the central sacred effigy doesn't participate in the reconstruction of the image of the latter, and it is also left untouched by the operations of optical deconstruction and reconstruction through the faceted lenses; furthermore, the keys that appear in direct vision in St. Peter's hands, the Father of the Catholic Church, through the multiple refraction of multifaceted lens 'migrate' miraculously in the hands of Pope Urban VIII. The great intelligence and scientific depth that emerges from La Perspective curieuse, combined with his considerable practical and artistic skills, earned to Niceron, from General Father Lawrence of Spezzamo, the appointment as commis of Father François de La Noue $^{32}$ (or Francesco Lanovio, 1595 - 1670) and, also in 1639 , that one as a mathematics professor. With this position, he was sent at SS. Trinità dei Monti monastery in Rome, where he met the erudited Father Emmanuel (or Emanuel) Maignan with whom, as remember by Bonnard, "... he will address, in addition to the specifically ecclesiastical sciences, a thorough study of Hebrew and optics." ${ }^{33}$

The first Roman stay of Niceron is registered in the convent's Conclusions Capitulaires, confirming its presence in the pincian complex from May 25, 1639 -

\footnotetext{
${ }^{32}$ See: Martin, R.P. C., late XVIII century. Histoire du couvent royal des Minimes français de la très sainte Trinité sur le mont Pincius à Rome. Manuscript of the convent of Trinita dei Monti (Ms. Trin.). p. 325 .

${ }^{33}$ Bonnard, Mgr. F., 1933. Histoire du couvent royal de la Trinité du Mont Pincio à Rome, A. Picard, Paris. p. 173. R.P. C. Martin (in Histoire du couvent royal des Minimes très français de la Sainte Trinité sur le mont Pincius à Rome, quoted before, p. 324) points out that "These two great men were definitely together for ten months and joined in their mathematical occupations, in the study of the Hebrew language, which was taught to them, and to the other, by a certain Francis hired for this from the community."
}

the date at which it becomes local and vocal - to March $28,1640^{34}$. The Roman convent, then under the aegis of the Carthusian Alphonse-Louis du Plessis de Richelieu (1576-1654), brother of the more famous and powerful Armand-Jean du Plessis (1585-1642) - best known as Cardinal Richelieu - advisor of Luigi XIII, allowed the two Minim brothers to share, in addition to the common religious feeling and the same passion for mathematics and physical sciences, an obsessive interest in one aspect of perspectival representation, strongly imbued with philosophical and esoteric echoes: that of the anamorphosis, which will see them involved in the realization of a unique and uncanny cycle of paintings. The theoretical and applied work of Niceron appears, to those who approach it with a critical look, closely linked to the one by Father Emanuele Maignan (1601-1676), and thus it is by taking account of this relationship $^{35}$ that we must investigate some of the speculative and artistic activities of our thaumaturgus opticus in the site of the Roman monastery [4].

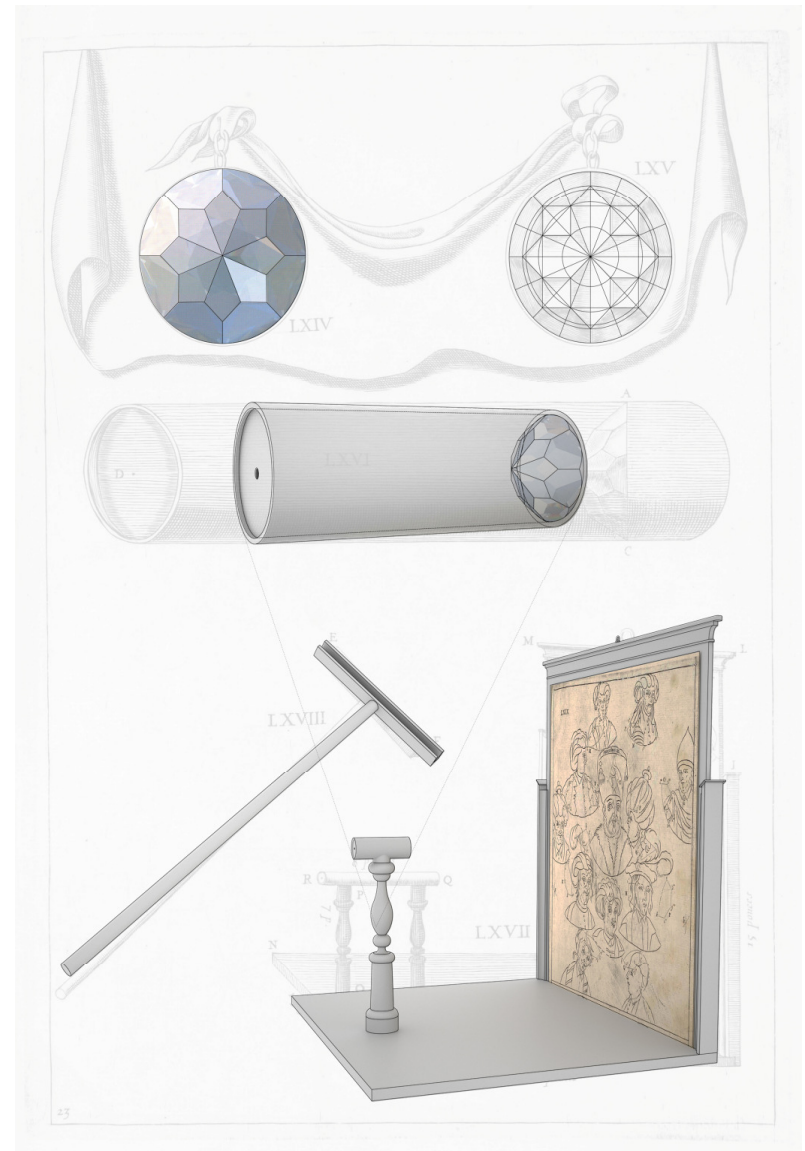

Fig. 2. Digital reconstruction of plate number $23 \mathrm{r}$ after J. F. Niceron, La Perspective Curieuse, Paris 1638. Digital drawing by $A$. Bortot/Imago rerum.

\footnotetext{
${ }^{34}$ AGM, XVII century. Livre des Conclusions Capitulaires de ce convent de la S.te Trinitè Du mont (5-X-1620 -26-IX- 1649). (T3). This is also confirmed by R. P. C. Martin (in his Histoire du couvent royal des Minimes très français de la Sainte Trinité sur le mont Pincius à Rome, quoted before, pp. 324 and following).

${ }^{35}$ See: Bessot, D. 1992. La perspective de Nicéron et ses rapports avec Maignan, in Bucciantini, M., Torrini,M., edited by, Geometria $e$ Atomismo nella Scuola Galileiana. Leo S. Olschki, Florence. pp. 1734
} 
The Convent's facing north corridor, where even today it's possible to admire the extraordinary catoptric astrolabe (1637), is followed - in ambulatory order (in clockwise direction) and in chronological order - by the long corridor which houses the 'perspectival painting' (1639-1640) made with colors with tempera, by father Jean-François Niceron: this dizzy anamorphosis inspired, by his own admission, the next (1642) anamorphic work by father Maignan, depicting in grisaille the founder of the Order, St. Francis from Paola. The mural painting was probably executed in a relaxed atmosphere of collaboration between the two confreres, if we consider their presence in the Roman convent, and even because Niceron (then twenty-nine years old) had been, previously, fellow of Maignan (then forty-one years old) always at the College of Trinita dei Monti in his first Italian stay from May 25, 1639 to 28 March 1640. At the expiration of his first stay in Rome, on the way back to Paris, Niceron contributed to the campaign undertaken, on behalf of Athanasius Kircher, by many contemporary scholars to measuring the declination with the magnetic compass in various geographical - Italians and foreigners - sites. In particular, our Minim father executed the commissioned survey at Rome, Florence and Ligurno (perhaps Livorno, the biggest port in the Grand Duchy of Tuscany) twice.

In a letter from Kircher to Niceron, now kept in the Historical Archive of the Pontifical Gregorian University $^{36}$, it's possible to read that survey's organization had difficulty performing in Florence, due to a virulent epidemic of plague that afflicted the city that year; however he promises to continue the operations, started in Italy, in France, notably in Lyon and Paris ${ }^{37}$. Niceron's interest towards geo-astronomical issues was renewed after a few years, when he provided, at the Place Royale monastery (Paris), a Selenography (lunar map) now disappeared. Probably it was a copy of an original lunar map made in Brussels by MichelFlorent van Langren, published by him in the April of that year, and which Niceron perhaps saw, in draft form, during one of his institutional travel on Netherlands. In 1640 Niceron is therefore at the main convent in Paris, first with the task of completing his theological training and, subsequently, after the transfer at the Collège de Nevers, performing the function of fellow of Auxiliary Visitor of the Order, François de La Noue (1597-1670), a pupil of Mersenne, at other Minim - French and Catalan - convents. The attraction towards what is hidden and secret, in art as in literature, however, never abandoned Niceron who in January 1641 became deeply involved in another 'deceptive' cultural project: the French translation and adaptation of L'interpretazione

\footnotetext{
${ }^{36}$ APUG 557B, faI. 383 $3^{\mathrm{r}-\mathrm{v}}$ Lat. Lugdunii, Kal. Maii 1640. Cfr Gramatowski, W., Rebernik, S.I. M., 2001. Epistolae Kircherianae. Index alphabeticus, index geographicus. Institutum Historicum, Roma. p. 82.

${ }^{37}$ See : Flelchef, J. E., Spring 1970. Astronomy in the Life and Correspondence of Athanasius Kircher, in Isis. Vol. 61, Nnumber. 1. p. 60 .
}

delle cifre $^{38}$, an Italian treatise on cryptography by Antonio Maria Cospi (or Crespi), in which the original contribution by the Minim father is the examination of the differences between de-encryption in Italian, French and Spanish, languages he deeply knew and got accustomed with during his travels and exchanges of correspondence with the scientific community of his time. Although the delicate issue of 'empty' appears, in the context of scientific-artistic Niceron's activity, on the background if compared to the contemporary debate, this issue exerted a direct or indirect, express or only alluded, influence on his major works, as can be deduced from the decoration program of the upper galleries of SS. Trinita dei Monti (Rome) painted by himself and Father Maignan, according to an unprecedented steganographic and astrolabic project.

It was here, between mid-1639 and early 1640, that Niceron executed the large anamorphic colored mural painting - then replicated, with significant differences, in 1644, in Paris at Minims' Motherhouse in Place Royale - depicting St. John the Evangelist writing his Gospel in the island of Patmos, and that father Maignan created, in 1642, the anamorphc portrait in grisaille of Order's founder, St. Francis of Paola in prayer ${ }^{39}$. With the restoration work completed (February 2009), Niceron's work now presents itself with wide gaps, but its total intelligibility remains: first, it was demonstrated that it is a fresco-secco mural painting. This information is significant, because the analysis of Niceron's curriculum vitae et studiorum has not yet revealed anything of artistic high-level apprenticeship character: because even the anamorphosis of San Francesco di Paola and catoptric sundial, twice painted by Maignan, were executed with the same technique, it must be deduced that it was adopted by the two scholars because of the lower degree of experience that it sought. Obviously, the choice of fresco-secco painting applies to a program of executive simplicity and velocity ensured perhaps by Niceron himself, who had already demonstrated considerable skills in the field of decoration and design: it was an ideal technique, therefore, to translate quickly into painted forms a complex optical-mathematical theorem, checking and correcting the image as it was processed, not in a fragmentary way, as the fresco would have required, but as a whole.

The strong optical compression produced by the oblique observation probably would have made it difficult to control every single working day. The

\footnotetext{
${ }^{38}$ Cospi (or Crespi), A. M., 1641. Les Interpretation des chiffres, ou bien entender Règle pour toutes et expliquer facilement sortes chiffres de simples. Tiré de l'anglais du Sr Ant. Maria Crespi ... par F. F. I. N. P. M, Paris, A. Courbe. In- ${ }^{\circ}$, pp. IV-90. R.P. C. Martin (in his Histoire du couvent royal des Minimes très français de la Sainte Trinité sur le mont Pincius à Rome, quoted before, p. 325) argues that the work was translated by Niceron during his second stay in Rome, before he left the Roman Convent, in April 1642. This observation conflicts with other consulted documents: at the date of its publication (1 January 1641), however, Niceron resided at the Place Royale monastery, as evidenced by the signing appearing at the end of the same Epistre.

${ }^{39}$ See: Ceñal, R., 1952. Emmanuel Maignan su vida, su obra, su influencia, in Revista de Estudios Politicos. XLVI. pp. 111-149.
} 
projective - but not mechanical - operations of John's straight model translation into the oblique one, even if not explicitly declared pertaining to the work in question, were already present in Proposition II, in the three following corollaries and the plates 12 and 13 of La Perspective Curieuse's Book II (1638), where Niceron announces: "Provide the method to describe any kind of figure, images and pictures, in the same way as the chairs of the previous statement, that is to say, in such a way that they appear confused in appearance, and from a certain point [of observation] they perfectly represent a proposed object." 40 The proposed constructions replicate, with anamorphic purposes, the use of the distance point introduced by Niceron already in the 1st Book of his vernacular treatise, and they overlap to the square grid - in which are inscribed the faces of Jesus Christ and St. Peter -, almost like a twodimensional memory of Alberti's perspectival veil (1435) or Dürer' shutter (1525).

Despite its chromatic components are highly compromised, because only the $30 \%$ of the original Seventeenth-century colors remains, the mural pianting reveals still clearly all of his story-telling power, even exhibiting a remarkable sensitivity to the effects of atmospheric perspective, in association with narrative metamorphosis to which the image of St. John was submitted, becoming a medley of landscapes from the biblical echoes. The work, located in the eastern arm and, partially, in the northern corridor located at the Roman Convent's first floor, is a true monstrum, in the etymological sense of the term: "which shows what is admirable" (by the latin verb monere, to alert, to admonish), a sign of the divine presence and a wonder which seems to violate the laws of nature, but which also serves as a reassuring or disturbing memento to the observer and the faithful. A large olive tree stands on the corridor, extending itself on the barrel vault, and overhanging St. John who is leaning on the volume about whose pages he's writing, thanks to a quill (which, viewed from the front, becomes a waterfall), the fourth Gospel or the Apocalypse, although the latter hypothesis seems more plausible, for admission of Niceron himslef.

The anamorphosis is properly viewed from a station point located in the south-west, thus close to the beginning of the next corridor that hosts it, not far from the area where now the chapel dedicated to Mater Admirabilis is located. From the digital checks made by me and my team, it is clear that this punctum optimum is symmetrical respect the one expected in the western corridor, for the right observation of St. Francis of Paola. It is therefore probable, in accordance with the history of their works, that Niceron first has influenced Maignan's choices, not only in the projective setting, but also the configuration of the work's stage, both paintings being strongly affected by the presence of trees that surround the two portrayed saints. In addition, another tree, but broken and burned (as in the other anamorphosis!), emerges behind the San Giovanni's body: from its inside, but in the front view, the beholder

${ }^{40}$ Niceron, J. F., 1638. La perspective curieuse. Paris. p. 52. perceive the image of a burning city (Babylon?), as didactically recalls the engraved inscription very close AP VIII (Apocalypse, chapter 8, 1-7) - above which hovers an angel playing the trumpet. On the open page of the book supported by St. John's holy knees, seen frontally, images of animals appear to the viewer such as dispersed in a plowed field, whose furrows spread radially, anamorphosis of the lines hand-penned by the Evangelist. The (human or monstrous) figures are portrayed with discretion, so minute and accurate, and always choosing the tonally next to the background color which hosts it, and so they disappear when viewed obliquely as suggested by Niceron himslef.

The same is true for other figures, today only partially recognizable - human bodies which flee, a ruddy and horned devil, others flying angels -, or suggestive landscape elements - rivers, lakes and waterfalls, forests, palm trees and exotic flowers -, which reveal themselves only under a detailed and direct vision: well hidden in the scarlet cloak of St. John - with its progressively darkening tone, moving away from the point of the eye - you should conceal the apocalyptic harvest mentioned in AP XIV (18-20), while in his facial features it seems to recognize the vat from which, as it is said, will flow the river of correlated blood (which is the scarlet cloak of the Saint). Still a heraldic animal populates one of the dry branches of the great backdrop tree: it is an owl, reminiscent of the issue of Babylon's destruction to which we have already alluded, and here anticipated in subliminal form. Symbolic is also the role of the two birds which sit on the top of barrel vault's spring line: the largest one, a dove - allusive to the Holy Spirit -, hovers in the air, and on it a serpent - tempter of humanity - leans into space, partially coiled in a frond; the smaller volatile, a sparrow, sits at the lower branch, symbolizing the celestial world that is opposed to the terrestrial, again embodied by the tempter reptile. As recalled by Niceron in his Thaumaturgus Opticus, the mural painting also provided, along the shortened volume's spine, a long inscription in ancient Greek which reads as follows: "The Apocalypse of Optics, the Eyewitness of Apocalypse." ${ }^{41}$ The reference is clearly to the detector power (apokalypsis means revelation) implied on the one hand in the anamorphical magic of the work - which displays its contents only when viewed from a specific point of view, geometrically and spatially constrained -, and the other in the theological role played by St. John, alone among humans to have eyes so sharp to be able to contemplate the True Light of the Word: the eagle, theriomorphic attribute of the Evangelist, is the only living being able to soar so high in the sky to see direct sunlight without becoming blind. Niceron portrays it in foreshortening, next to the Saint, in a very advanced position: its beaked head and one of its spread wings (the other, falling in flawed area of mural painting, is lost) become, when viewed frontally, the backgrounds of a biblical landscape over which a declining sun is obscured by thick smoke, a prelude to the Parousia. Perhaps the choice of such an atypical subject (for

${ }^{41}$ Niceron, J. F., 1646. Thaumaturgus Opticus. Paris. p. 177. 
Niceron's mural painting) is to be found in this critical juncture: not being object of special veneration by the French Minims, St. John's figure must have been chosen for its complex ethical-philosophical level, on the one hand able to bring the word Logos (greek for verb) to God, thus reconciling the Christian culture with a Jewish-Hellenistic vision of the world; and on the other for the absence of deliberate abstraction that characterized his testimony of faith, he referring in his Gospel only to "...what we have heard, which we have seen with our eyes, what we beheld, and what our hands have touched ... life was made manifest." Thus he was the eye witness of the living Logos, epithet with which John loved to be defined (First Epistle of John), as well as the Minims fathers, contemporaries of Niceron's pictorial work, were the first eyewitnesses of anamorphosis' scopic catastrophè, startled and then reassured by its continued optical composing and decomposing. But in this act of witness, assigned by Niceron to the opticery of his painting, it still seems possible to see an item attributable to the Cartesian speculation.

It is perhaps to this cultural environment that it has to be ascribed the Latin inscription that adorns the pendant cartouche from one of the branches placed over the back of St. John, where we read: "CITRA DOLUM FALLIMUR" ("we are deceived without malice"). As emphasized by Fratini and Moriconi ${ }^{42}$, it is a calque by the motto which accompanied the title of the famous Perspectivae Libri Sex (Pesaro 1600) by Guidobaldo del Monte (1545-1607), an author to which Niceron in his two treatises often refers, underlining its rigorous mathematical and proto-projective approach sometimes excessively abstract and complex - to perspective; but as well as being a tribute to one of the most authoritative sources of science that the author most profitably cultivated, the writing could be invoked to suggest here, thanks to its inclusion in a mural anamorphosis, a critical reflection on the exercise of the doubt. Indeed, the presence of this and other pictorial and decorative works, which adorned both Roman and Parisian Minims' monasteries, if on one hand they constituted a real breeding ground in which to test the experiments in optical and figurative painting theoretically elaborate and performed in vitro in treaties and studies, on the other hand they were the subject of a powerful reflection on the Cartesian labyrinthine character of the visible and on the falsa credita which derived from it. In the plate 33 of the Thaumaturgus opticus (1646), Niceron provides a graphical summary of the projective method ${ }^{43}$ he probably employed to achieve the anamorphic work in the Roman monastery, but for sure he used also for the twin anamorphoses he

42 Fratini, G., Moriconi, F., 2010. Datazione e attribuzione dell'anamorfosi di San Giovanni a Pathmos presso il Convento della Trinità dei Monti a Roma, in MEFRIM: Mélanges de l'École française de Rome. Italie et mediterranée. T.. 122/1: École française de Rome, Rome. pp. 128-129..

${ }^{43}$ D. Bessot (in Id., La perspective de Niceron et ses rapports avec Maignan, quoted before. p. 164) suggests Niceron employed a mix of a projective-geometric method (already examined by the author in his La Perspective Curieuese) and of a mechanical one. did Paris: it's possible to recognize the ectipo - drawn in black-and-white, and placed obliquely respect the wall surface - of St. John's rectified portrait, inserted in a network of orthogonal lines [5]. In the text (Book II, XI proposition, III corollary) Niceron clarifies the nature of portrayed subject and the color attributes of the dress (green) and of the Holy cloak (purple), while not pointing to any source of inspiration: "Among the painters, it is accepted for common use and as usual the fact that, when they foreshadow the image of St. John the Evangelist, they represent the robe with the green and the cloak with the purple." ${ }^{44}$ It is a reconstruction by heart - and obviously with a didactic purpose - of the sinopia on which it was based the anamorphosis made in Paris, in the galleries of Place Royale's Convent, by Niceron himself around 1645, shortly before his death, according to a precise decorative program. So he describes his work in Paris with these words: “... Instead, by that one drawn here in Paris we show directly in BCDE the prototype from which, by means of the exposed method, the projection was obliquely transposed on the wall.

As we have already said, this is not to be seen as a nude projection with oblique rays, but in it are offered to a direct view many other objects not disagreeable or ugly: here, we have them listed and provided as an example, especially because, at a given circumstance, a similar reproduction might be attempted, and even obtaining one more beautiful and elegant." ${ }^{45}$ Remarkable is the size that the anamorphic painting had to reach, as it was placed in an ambulatory: ".. long twenty-four feet $(33,78 \mathrm{~m})$, where the aforementioned image projection covers fiftyfour feet in length $(17.54 \mathrm{~m})$ on a wall of at least eight feet in height $(2.60 \mathrm{~m})$, and the ocular point which is perpendicularly at five feet $(1.62 \mathrm{~m})$ from the wall or delineation surface, it rises above the floor only four and a half feet $(1.46 \mathrm{~m})$. We could not delineate with these proportions the given figure, because of the table's anguish where we located it." ${ }^{46}$

Surely, Niceron's pictorial invention had to overcome all those hitherto executed, both for the choice of a religious theme so topical for Christianity the revelation to the Saint of the end of Times and the beginning of the New Kingdom -, but also because the landscape hidden in the anamorphic portrait, as already in his Roman St. John and in the San Francesco di Paola by E. Maignan, had to show a second and more dramatic exegetical level: shadowed with soft colors and attenuated appearances, so that “... instead we are no glimpsed from a distant and oblique point of view" ${ }^{\prime 4}$, walking along the portico, they could contemplate so “... in the dark and shadowy folds of green tunic, [...]intricate forests and dense woods of impenetrable trees. In tunic's more enlightened parts or in foreground, [...] instead blondes ears and already ripe harvest.

\footnotetext{
${ }^{44}$ Niceron, J. F., 1646. Thaumaturgus Opticus. Paris. p. 177.

${ }^{45}$ Ivi. p. 176.

${ }^{46}$ Ivi. p. 178. The foot which is referenced by Niceron is the Parisian foot equal to $0.3248394 \mathrm{~m}$.

${ }^{47}$ Ivi. p. 177.
} 


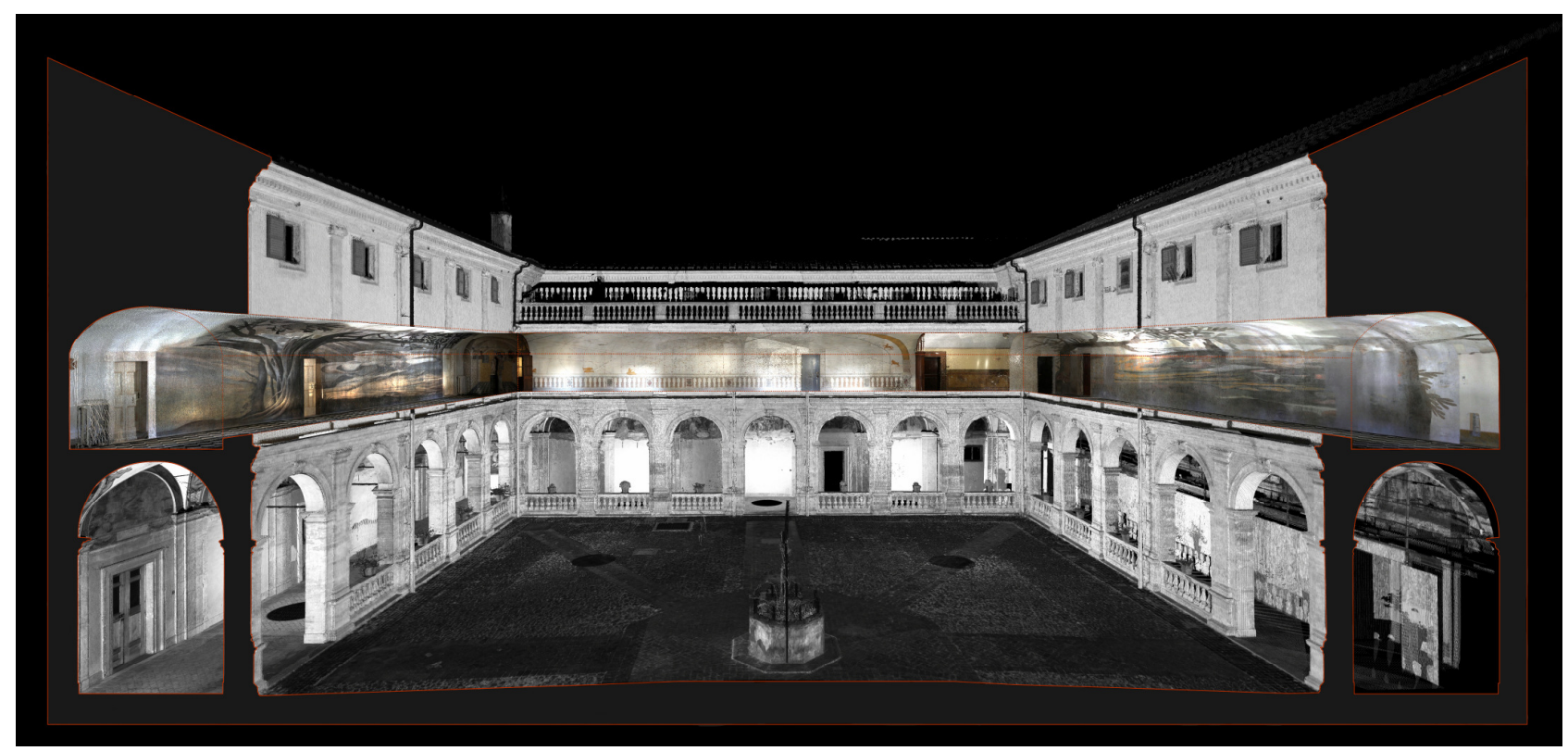

Fig. 3. The monastery of SS. Trinita dei Monti, Rome. Perspectival section on the eastern and western corridors. Digital images by A. Bortot and C. Boscaro / Imago rerum.

In his candid belt, flowing water from rivers and spring; in white sheets of the open book, a large lake, and in it a harbor, beaches, ships, fishing etc. In the head, caves, caverns, steep cliffs, rocks, buildings: rather, the ruins of the whole city of Babylon, next to which we place even of angels playing the trumpet." 48 Only by moving away from what Niceron defines ocular point - perhaps placed on the corridor threshold's entry which allowed the access to the library of the Convent of Paris-, visions and mysteries appeared narrated by Apocalypse's various chapters and are reproduced figuratively in a growing vertigo of sight so compelling that the author himself, disinclined to the self-celebration if not for purely rhetorical purposes, had to admit it had been reported to it by the Greek words which he had painted on Evangelist's book. "«The Apocalypse of Optics, the Eyewitness of Apocalypse» [...] Thus, in the pages of the open book, between the lines of written text or between the verses we represented land furrows, and in them that grazed flocks and shepherds that guarded them; so, in the purple cloak of our Evangelist I represented the harvest which, in the fourteenth chapter of the Apocalypse, is said to be whipped up horse bridles and to be flowed to one thousand six hundred stadia; in addition, we represented in heaven, sitting on a cloud, the one who sank the sickle into the earth and sent the angels to harvest the grapes of the vineyard. Rather, even from the face's features, by applying suitable colors, we painted with care a barrel or a cask from which, crushed grapes, flowed the harvest." 49 From the comparison between Niceron's Roman painting (finally visible today), and

\footnotetext{
${ }^{48}$ Ivi. p. 177.

${ }^{49}$ Ibid. In the text, the quotation is in ancient greek and it plays on the possible translation of the word 'apocalypse' as 'unveiling', implied operation also in the decoding of anamorphic image.
}

niceronian drawing by the lost Parisian anamorphosis the only surviving evidence of its original look -, it is clear that the postures assumed by the Saint in the two images were totally different: in Rome, San Giovanni is bent forward, leaning on the page where he is writing the Apocalypse, his gaze focused on the drafting of the prophecy which reifies in biblical episodes anamorphically hidden in the surrounding landscape and in that created by his body, and above all, decisive element, the eagle, his theriomorphic attribute, appears in front of his body; in Paris, however, the Saint is portrayed in a proxemically open posture, not poured on the tome, which also backs to his legs tight around the eagle's neck. In Niceron's drawing the gaze of the subject is directed exactly to the library of the Convent of Paris, while barely hinted landscape - composed of a tree on which is screwed a branch by ivy and of rocks placed on the background - appears suggesting its 'narrative' development in its anamorphical transformation: therefore it's not possible to infer a logical correspondence between the figurative structure of the image and the biblical episodes which should have been concealed in it, although described in the posthumous treatise by the author. Thus in that work Niceron theorized how anamorphosis could be applied to extensive wall surfaces, allowing the creation of real own murals, like those he already executed in Rome and Paris. In particular, in addition to the anamorphic representations, of which we have spoken, depicting St. John the Evangelist in the two famous Minims' Convents, the author realized in the Paris Coenoby another prospectively accelerated painting (we assume executed in fresco-secco painting) - 'en perspective' according to Convent's Annals ${ }^{50}$ - which had as subject

\footnotetext{
${ }^{50}$ Mazarine Archive, 2429, Annales des Minimes de la Place Royale, p. 172. The italians anamorphic frescos painted by Niceron and
} 
The Magdalene contemplating the Sainte-Baume (1645), and which was finished, after Niceron's sudden death, by Father Maignan visiting Place Royale, in 1662. In creating the extensive Parisian paintings, we know that Niceron adopted a similar approach to that one by Maignan, taken directly from Dürer's 'small door', and upon which the author discusses extensively in the Thaumaturgus opticus's aforementioned table: also Niceron employs a 'fork' to which connect a sliding plumb line which allows the identification of rectified portrait's point to be anamorphically projected, hinged to the wall of the mural painting.

However, this work, like the survivor one by Maignan, entrenches the overcoming of Alberti's and Dürer's perspective imagined as an open window on a reality which is offered to painter's eyes, because now the anamorphic frame is already fitted with a perspectival image, that one drawn in true form inside a squared network that will be projected on the wall surface: therefore it doesn't exist any longer "... the intersection of the visual pyramid that separates the subject from the object, or the simple projection of the object on the plane of intersection. Now, on the plane there are depicted images projected by the mind."51

\section{CONCLUSION}

We have now reached the last years of father JeanFrançois when he, back in Paris, focused on his cenobitic commitments: ordered by his Superiors to complete his theological studies, he saw more and more limited, by the conventual and doctrinal responsabilities, the opportunity to continue, as he probably would have liked, his optical-perspectival experiments, the value of which was still very present in international scientific and religious communities, as evidenced by, among other things, the fact that the envoy of the famous Grand Duke of Tuscany Ferdinando II, Giovanni Francesco Rucellai, during his stay in Paris, visited Place Royale's monastery (June 24 1643) and saw "some curiosities in perspective" by father Niceron, exposed in the monastery library.

Even Thaumaturgus opticus's writing activities experienced some heavy delays during this period, due to the same reasons: we learn it from a letter sent by Niceron to Gabriel Naudé on 14 May 1645, which shows how the Minims father had imagined to employ only four or five months for the subsequent preparation of his treatise's Latin version, but that at that time he had reviewed only for the first half ${ }^{52}$. Before being sent to the Collège de Nevers, that hosted him as novice, and

Maignan were seen by Father Mersenne in his journey to Rome, in 1644.

${ }^{51}$ Ciucci, G., 1982. Rappresentazione dello spazio e spazio della rappresentazione, in G. Ciucci, M. Scolari, edited by, Rassegna. Rappresentazioni. Number 9, Milan. p. 11. See also: Camerota, F., 2006. La Prospettiva del Rinascimento. Arte, architettura, scienza, Electa, Milan. pp. 194-195.

${ }^{52}$ Liceti, F., 1640-1650. De quaesitis per epistolas a claris viris responsa...7 voll., Bologna and Udine. vol. III, 1646, pp. 225-8 (letter from Niceron to Gabriel Naudé, Lyon, May 15 1645). then "... called to the General Visitation of all France's provinces, and designed as a colleague on the much learned and wise admodum Rev. P. François La Noue, Vicar of our Order in France and worthy General Visitor..." ${ }^{53}$, tired by the constant travels and by the austere lifestyle imposed by Order's rule - including a strictly Lenten diet -, Niceron became seriously ill during a Générale visits in the Midi-de-France (Provence) and in Cataluña, following father François de La Noue, a friend of Mersenne, being initially admitted to Minims's convent of at Pourrieres (founded in 1568), in the municipality of Usseaux, and expiring September 22, 1646, at age thirty-three years (and 14 of priestly profession), at the convent of Notre-Dame-dela-Seds in Aix-en-Provence. Niceron's beautiful portrait, executed by Michel Lasne, of which we have spoken at the beginning of this essay, delivers him to posterity in a hieratic pose, while his right hand, as well as a compass, sustains the table 13 of Thaumaturgus opticus which represents, in perspective, a complex starry polyhedron. This work, as mentioned previously, saw the light in Paris in 1646, for the types of Francois Langlois, after the death of its author: in this case, this is a in-folio volume, dedicated to Cardinal Mazarin (16021661), characterized by 25 initial unnumbered pages containing the Dedication, the Print Permission, the Summary of the content and the Preface -, 221 numbered pages, 30 unnumbered and 42 plates. Title page's chalcography is drawn by Simon Vouët, while internal plates' engravings are probably to be credited to Jean Blanchin and Charles Audran.

The story begun a few pages ago - that is a few centuries ago, and lasted only thirty-three years - is about to end. But we do not want to leave the reader without a final image, after the tumult of figures, patterns, distortion, anamorphosis and reflections which have populated this essay. Following the suggestions contained in an article by Paul Gagnaire ${ }^{54}$, we invite you to look at the table which accompanies the Propositio LVI (56) of Emanuel Maignan's treatise about sundials, Perspectiva horaria ${ }^{55}(1648)$ : in it we see a perspectival render of the other famous catoptric sundial, made in Rome by by the Minim father from Toulouse, at Palazzo Spada ${ }^{56}$, now home of Italian Council of State. As you know, the work was carried out in 1644 on behalf of Cardinal Bernardino Spada protector of Minims' Order, the image of whom accompanies three other visitors: he was in fact the character at its right end, wrapped in a hood, with a hat in his hand and with the unmistakable goatee immortalized by Guido Reni in a famous portrait (1631), now in the Galleria Borghese. The identification of the other three defendants is more complex: the Cardinal turns his gaze in an area of

\footnotetext{
${ }^{53}$ Niceron, J. F., 1646. Thaumaturgus Opticus. Paris. p. XXII.

${ }^{54}$ See: Gagnaire, P., Summer 2003. Le cadran solaire à réflexion du Pére Maignan, à la Trinité des Monts, in ANCAHA. Number 97, without place.

${ }^{55}$ See: Maignan, E., 1648. Perspectiva horaria. Rome. p. 390 and following.

${ }^{56}$ See: Neppi, L., 1975. Palazzo Spada. Editalia, Roma.
} 
frescoed vault where the central character points his index; he's a nobleman with a cloak which draws to us his back, perhaps interested in focusing on the gnomonic issues depicted on the sundial.

A hallmark to understanding his identity could be the pink fabric attached to a flap of his breeches, the heraldic symbol of the Orsini family. Beside him, on the left, two friars face each other: the garment they wear is the patience of Minims' Order. So it would not be much to assume that one of the two characters is the inventor of the sundial, Emmanuel Maignan. The outermost one directly shows his face, face up, also attracted by the gnomonic problem raised by the noble stranger. The haggard features, his haunted eyes and shaved heads might lead us to identify him with Jean-François Niceron $^{57}$, while the father who turns back on us, more robust and with an evident tonsure, suited to his priestly rank, would seem Father Maignan. But even in this image, as in Lasne's portrait, with which we opened our essay, it sneaks a space-time paradox: here it would be the portrayed Niceron's ghost, since he died in 1646, two years before this image was drawn. Niceron was never in this gallery, even before that fateful date, since the parable of his short stay in Rome last ended in October 1642. This image would assume, under the light of the scientific relationship and discipleship between the two Minims, a deep human significance: Maignan would have wanted at his side, even for once, even if only in an image, the friend with whom he had shared academic and theological reflections, decorative projects and wonderful visions hidden in the body of the artificial magic.

\section{IOANNES FRANCISCVS NICERONVS. SENSIS NOVA NVNC RARE CONFICI}

\section{REFERENCES}

[1] Baltrušaitis, J., 1984 (italian version). Anamorfosi o Thaumaturgus Opticus. Adelphi, Milan.

[2] Baltrušaitis, J., 2007 (italian version). Lo specchio. Rivelazioni, inganni e science-fiction. Adelphi, Milan.

[3] Bessot, D., 2005. Synthèse et développement de techniques d'anamorphoses au XVIIe siècle : les traités du pére Jean-François Niceron, in MEFRIM: Mélanges de l'École française de Rome. Italie et mediterranée. Vol. 117, 1, Rome.

[4] D'Acunto, G., April-June 2006. Jean-François Nicéron's Thaumaturgus opticus: between scientific precision and natural magic, in Bollettino Ufficiale dell'Ordine dei Minimi. Number 2, year LII.

[5] De Rosa, A., 2006. The Optik's Apocalipse. The twin anamorphosis by Emmanuel Maignan and JeanFrançois Nicéron, in Ikhnos. Lombardi. Siracusa.

[6] De Rosa, A., Bortot, A., Boscaro, C., Monteleone, C., Trevisan, E., 2012. Memory and oblivion.
Discovery and digital survey of J.-F. Niceron's mural anamorphosis, in Acts of XVI ASITA National Conference, Vicenza.

[7] De Rosa, A., D'Acunto, G., 2002. La vertigine dello sguardo. Saggi sulla rappresentazione anamorfica. Cafoscarina, Venezia.

[8] De Rosa, A., edited by, 2013. Jean François Nicéron. Perspective, Catoptric and Artificial Magic, with critical editions of La Perspective Curieuse (Paris 1638) and of the Thaumaturgus Opticus (Paris 1646). Aracne edizioni, Rome.

[9] Fratini, G., Moriconi, F., Datazione e attribuzione dell'anamorfosi di San Giovanni a Pathmos presso il Convento della Trinità dei Monti a Roma, in "MEFRIM: Mélanges de l'École française de Rome. Italie et mediterranée", t. 122/1, École française de Rome, Roma 2010.

[10] Massey, L., 2007. Picturing space, displacing bodies. Anamorphosis in Early Modern Theories of Perspective. Pennsylvania State University Press, University Park.

[11] Rizzini, I., October-December 2004. Jean-François Nicéron's Thaumaturgus opticus: notes on translation from Latin, in Bollettino Ufficiale dell'Ordine dei Minimi. Number 4, year LI.

[12] Whitmore, P. J. S., 1967. The Order of Minims in Seventeenth-Century France. Springer, The Hague

\section{ЖАН ФРАНСОА НИСЕРОН: ПЕРСПЕКТИВА И ПАТВОРЕНА МАГИЈА}

\section{А. де Роса}

Есеј се бави уметничким радом на перспективи Жана Франсоа Нисерона (1613-1646), фратра реда Минима, чији је живот трајао само 33 године, али је био испуњен политичким и културним догађајима, што се огледа у радовима који се данас нуде оку савременог посматрача као шарада савршене равнотеже између математичке строгости и склоности за чудесно и невероватно. Аутор две расправе (друга је објављена постхумно) које су постале прекретница у изучавању перс-пективе у 17. веку - La perspective curieuse, (Чудновата перспектива), Париз 1638. и Thaumaturgus opticus, (Анаморфозе), Париз 1646, Нисерон је рано изашао из свог света експресије преводећи га у критички варљива дела: катоптичке анаморфозе, рефрактивне игре и мурале у „скраћеној-брзој“ перспективи (једино сачувано дело приказује Светог Јована Богослова како пише Апокалипсу у Патмосу, а које се данас може видети у цркви Trinita dei Monti y Риму), да поменемо само неколико врста његових дела.

\footnotetext{
57 The other hypotheses that we could advance, more plausible in terms of historiography, is that one of the two Minim Friars is Marinne Mersenne who stayed in Rome just in the winter of 16631644.
} 